\title{
Development of Teaching Materials of Poetry Writing Using Pictures for the Elementary Students
}

Satinem*, Juwati

Indonesia Language Education Study Program, STKIP PGRI Lubuklinggau, Mayor Toha Street, Lubuklinggau City, South Sumatera, Indonesia

Corresponding Author: Satinem, E-mail: satinem@stkippgri-lubuklinggau.ac.id

\section{ARTICLE INFO}

Article history

Received: January 10, 2018

Accepted: March 19, 2018

Published: June 30, 2018

Volume: 9 Issue: 3

Advance access: May 2018

Conflicts of interest: None

Funding: The research is financed by

STKIP PGRI Lubuklinggau.

Key words:

Writing Poetry,

Assisted Picture,

Teaching Materials,

Research and Development

\begin{abstract}
The research aims to develop the product of Teaching Materials of Poetry Writing Using Pictures. This developed teaching material result is expected to be used by the students of grade $\mathrm{V}$ of SD Xaverius Lubuklinggau, SD Negeri 44 Lubuklinggau, and SD Negeri 20 Lubuklinggau in learning to write poetry.The method used in research is research and development or better known as R \& D.If the calculation of the data is smaller than the alpha value (0.05), it means that there has been a significant difference before it is used after the use of poetry writing materials compared to the KKM of each school, so that the Teaching Materials of Poetry Writing Using Pictures is declared effective. From the calculation bySPSS, the results obtained for the test value $\mathrm{t}_{\text {count }} 11.219$ and $\mathrm{t}_{\text {table }} 2.045$ for (d) 30 and alpa 0.05 in high level group students of SD Xaverius. While for the average level group shows the value of $t_{\text {count }} 9,416$ and $t_{\text {table }} 2.042$ for (d) 30 and alpha 0.05 . For the low group level, gained the $t_{\text {count }}$ value of 4.859 and $t_{\text {table }} 2,110$ for (d) 17 and alpha 0.05 , thus it can be concluded that $t_{\text {count }}>t_{\text {table }}$, so H0 is rejected, and H1 is accepted. In the other word, it can be concluded that $t_{\text {count }}^{\text {count }}>t_{\text {table }}$, so that $\mathrm{H} 0$ is rejected.Based on $t$ test result from three schools, it can be concluded that $t_{\text {count }}>t_{\text {table }}$, so $\mathrm{HO}$ is rejected, and Ha accepted. The average value of learning completeness after using writing materials is the same or greater with the Minimal Completeness Criteria (KKM) in each school, meaning that the teaching materials is effective used to improve the students' ability in writing poetry.
\end{abstract}

\section{INTRODUCTION}

Writing is an activity that is productive and expressive. Although it looks easy, in reality not everyone is able to write. This is because writing is a complex activity and does not come for granted, but through continuous practice. This is in line with Tarigan's (2008) opinion that writing skills do not come automatically, but must be through practice and practice regularly. On the other hand, Dalman (2014) also says that writing is an activity of pouring ideas, opinions, feelings, desires and wills as well as information into written language. While desire and willingness or motivation, according to Murphy and Alexander (Zafarmand, Ghanizadeh, \& Akbar, 2014) there is a very close relationship between motivation and learning achievement. This means that the achievement or the success of students in writing activities one of which wrote poetry is determined by the motivation embedded in students to pour their creative ideas into each bais-line of poetry.

Poetry is a beautifully arranged word. Each word contains various meanings to be expressed by the author. This is in line with the opinion of Pradopo (2005) that the poem is the most beautiful words in the most beautiful arrangement. The poet chooses the right words and arranged well balanced, sym- metrical, between one element and the other. Wahyuni (2014) says that poetry is a recording and interpretation of human experience that is changed in the most meaningful form by providing beautiful language. Poetry as a type of literary work must also be through a creative process in the form of written or printed beauty value in terms of diction and typography (Wellek and Warren in Noermanzah, 2017).

Learning poetry writing is done with the aim to improve students' ability in pouring a reality of life that exist in society through beautiful and interesting language. It is said to be beautiful and interesting, because poetry expresses thoughts to evoke feelings, which are capable of stimulating the senses of the senses in a rhythmic arrangement. In other words, writing poetry is a creative expression, born from the expression or activity of the soul through the centralization of the implied message to the poetic connoisseur. A writer can utilize a number of mechanical language tools consisting of paragraphs, sentences, vocabulary, diction, and spelling in expressing his ideas and ideas.

In fact, there is a very poor condition which has so far been overlooked by educators and associated with the educational task of writing poetry materials. Teaching materials to write poems that are believed to overcome students' 
difficulties in writing poetry have not been developed by educators. To overcome these conditions required creative and varied ways as an effort to inspire the passion of learners to be motivated in the activities of writing poetry. One way that teachers can do so that learners interested in writing poetry is assisted with images that are packed or designed in a special material to write poetry.

Currently, the study of poetry writing tends to be informative rather than productive. That is, the learning created by teachers in the classroom to provide information literary knowledge so that the ability to appreciate and the ability to create literary works, especially poetry received less attention. Thus, what happens is the process of transfer of knowledge about literature from teachers to learners. The impact of these learning conditions, students lack the opportunity to do the construction of knowledge and develop it into a product of new knowledge in the form of literary inventiveness.

Based on observations in the field, the existence of teaching materials or books in school libraries that became the object of research that is SD Xaverius, SD Negeri 44, and SD Negeri 20 in Lubuklinggau City who examine and discuss about the writing of poetry accompanied by clear work steps are very minimal. Even from the three schools that make the research setting, there is not a single teacher who makes their own teaching materials for the process of teaching and learning activities. The evidence suggests that the material of writing poetry that has its own characteristics has not been a priority over the development of literature in general. Though the child's skills to pour ideas into interesting writing is an important element to improve the appreciation and love of children to literature earlier.

Teaching materials play an important role in improving student learning outcomes. Therefore, to improve the quality of learning to write poetry, it is necessary to develop practical, effective and innovative teaching materials. However, based on the results of interviews with teachers related to teaching and learning process, teachers use teaching materials that are already available that is electronic school books (BSE) as a learning resource without any effort to plan, prepare, and prepare their own teaching materials. This fact is in line with the opinion of Prastowo (2011) that many educators are still using conventional teaching materials, which is teaching materials to live with and stay bought without any attempt to compose their own. Thus, it is possible if the teaching materials used are not contextual, unattractive, monotonous, and not in accordance with the needs, both teachers and students. As an educational practitioner of course concerned for such conditions, then through this research the author wants to provide examples of teaching materials that are designed in accordance with the needs of students and teachers. To know whether or not the quality of a teaching material, it is necessary to evaluate. This is stated also by Cunningsworth (cited by Alkhaldi, 2010: 284) that evaluation is needed to identify the points of strength and weakness of teaching materials, while Mukundan (cited by Alkhaldi, 2010: 284) says that material evaluation is necessary to achieve learning objectives.

The problems in this research are 1) how the Teaching Materials of Poetry Writing Using Pictures that suits the needs of elementary school students and teachers in Lubuklinggau city; 2) how is the Teaching Materials of Poetry Writing Using Pictures developed in Lubuklinggau city; 3 ) how is the feasibility of the Teaching Materials of Poetry Writing Using Pictures of Grade V elementary students in Lubuklinggau city; 4) how is the effectiveness of the application of the Teaching Materials of Poetry Writing Using Pictures on the students of grade $\mathrm{V}$ in Lubuklinggau city.

The reason that the researchers develop teaching materials in the form of poetry writing module is a) to facilitate the process of teaching and learning; b) to be effective and systematic; c) easy to use in understanding learning materials; d) as needed. Thus, the use of developed teaching materials results are expected to help teachers and students in learning to write poetry. This is in line with the opinion Setiawan (2007) that the teaching materials are considered something that can be utilized both by teachers and students in the learning process and aims to improve and improve the effectiveness of students' learning.

Based on the problem, it is necessary to develop a practical, effective, and innovative poetry writing material to help students write poetry. Therefore, the researcher is interested to develop poetry writing materials equipped with specially designed poetry writing exercises and also equipped with steps and examples of writing poetry as an effort to overcome students' difficulties in writing poetry.

\section{RESEARCH METHOD}

The method used in this research is research and development or better known as R \& D. According to Sugiyono (2012), research and development is a research method used to produce a particular product, and test the effectiveness of the product. Furthermore, Sukmadinata (2008) defines research and development as a research approach to produce new products or improve existing products. Research and development is "a process used to develop and validate educational products” (Borg \& Gall, 1989). Thus, development research is a method to produce a particular product or refine an existing product and test the effectiveness of the product.

The subjects of the study were elementary school students of grade $\mathrm{V}$ in Lubuklinggau City as many as 3 schools with 79 students. Sampling was done by random sampling method, in which each level of school was determined by 1 class as research subject. A limited trial was conducted at SD Negeri 44 with a total of 31 students. In the implementation of the limited trial of teachers involved amounted to 3 people, namely teachers who are teaching in class V.

Extensive trials and implementation were carried out in 3 Primary Schools, i.e high, medium, and low level schools. Next is continued with the effectiveness test of teaching materials at SD Negeri 44 and SD Xaverius Lubuklinggau. The study was conducted using steps according to Borg and Gall. This research is limited to operational field test, that is, prototype of learning model of poetry writing followed by model implementation. Detailed steps research and development is as follows (Table 1).

Furthermore, data collection techniques were conducted into 2 types, namely quantitative data and qualitative 
data. Data on validation test of developed learning material obtained from 3 design experts. The three design experts include: the design of material experts i.e elementary school teachers where researchers conducted research, design experts by Dodik Mulyano, M.Pd., and linguists by Dr. Rusmana Dewi, M.Pd.

Data processing is done through qualitative and quantitative analysis. The data analyzed qualitatively are: 1) information about learning to write poetry; 2) inputs, responses and suggestions from the design of teaching materials to write poetry; 3) information from small group respondents; 4) input or data from teachers on developed teaching materials; 5) suggestions written by respondents when filling in a questionnaire on a column that has been provided. While the quantitative data obtained through the questionnaire needs students learn to write poetry and questionnaire product assessment from 3 experts described by percentage and then interpreted and explained qualitatively. To draw the conclusion of the effectiveness of product development of writing poetry teaching materials through pictures media developed using t-test with SPSS, it serves to know the difference in the level of students' ability to write poetry before and after using the development result of teaching materials. If the calculation result of significant data smaller than alpha value $(0,05)$ can be declared has happened significant difference, hence can be said that teaching material writing poetry teaching materials through pictures media is effective.

The development of teaching materials is done through four stages in accordance with research and development steps by Borg and Gall, namely 1) preliminary research; 2) development planning of instructional material model; 3) validation, evaluation, and revision of the model; 4) model implementation.

\section{FINDINGS AND DUSCUSSION}

\section{Result of Learning Material Need Analysis}

Based on the preliminary study, it was learned that poetry writing activities were taught to the students based on the package book. Teachers in the learning process rely on book packages that have been prepared from school. The three schools that are used as research settings do not have teaching materials that are designed by the teacher themselves. In general, preliminary study, resulted in: 1) an overview of the learning process of class V SD in Lubuklinggau; 2) an overview of the needs of the teaching and learning process and the need for learning models to write poetry of grade V SD in Lubuklinggau City; 3) learning model of writing poetry in accordance with the needs in the field; and 4) the effectiveness of learning models of poetry writing based on image media.

Questionnaires of teaching materials need of writing poems with the help of pictures presented openly, meaning that each teacher can provide answers in accordance with real conditions that exist in where they teach. Questionnaire given to the teacher contains 6 aspects, namely: 1) the love/ pleasure of students to write poetry; 2) The source book used by teachers in poetry writing; 3 ) the superiority of teaching materials; 4) weakness of teaching materials; 5) obstacles encountered in learning to write poetry; 6) teaching materials/poetry writing that the teacher wants; 7) displaying teaching materials to write poetry.

Assessment of peers conducted to obtain feedback, suggestions and criticisms of the teaching materials have been prepared by researchers. Input serves as a basis for improvements to the developed teaching materials.

\section{Needs of Syllabus}

The syllabus given to the teacher contains 4 aspects to be measured as follows: 1) Competency Standard; 2) Basic competence; 3 ) indicators; 4) goals. The following recapitulation of peer appraisal is related to the syllabus of poetry writing material developed in the study. The complete answer from 3 respondents can be seen in the following table 2 .

Based on peer assessment results related to the resulting syllabus, obtained the teacher information which states the syllabus is needed by $66.67 \%$ while the answer that the syllabus is required $33.33 \%$. Based on the table it can be concluded that in principle all teachers stated that the developed syllabus is needed in the learning process.

\section{Needs of writing poetry learning materials}

The following is a recapitulation of peer appraisal in relation to the poetry writing materials developed in the study. The complete answer from 3 respondents can be seen in the following table 3.

Based on peer assessment results, it was argued that the percentage of teachers' answers which states that the poetry examples contained in the teaching materials are in accordance with the needs in the field. The percentage of material stated in the materials is required by $53.33 \%$, which states required of $46.67 \%$, and which states less needed only by $0 \%$.

The result of the questionnaire assessment from colleagues stated that the writing material of poetry is really needed among elementary school students. The material of poetry writing has been ranked by the level of understanding of poetry, including: 1) The physical structure of poetry; 2 ) the inner structure of poetry, 3) the types of poetry.

Based on the data in table 3 , it appears that the writing material of poetry has been in accordance with the needs of the objectives, evaluation/training. There is a general purpose (in Syllabus) of learning with the specific purpose of learning (in the Lesson) writing poetry. The teaching materials have been completed with evaluation material at each end of the theme presented (given at the end of each KD), and there is an order to do the task either individually or in groups at the end of KD as an exercise.

\section{Teaching Material Model of Writing Poetry Using Pictures}

After the researcher analyzed the needs of students and teachers in the form of an open questionnaire given to students and two teachers, the researcher realizes contestual and pedagogic realizations. In the contextual phase, the 
Table 1. Step-by-step development of teaching material model of poetry writing using pictures

\begin{tabular}{|c|c|c|}
\hline Borg and gall main steps & 10 Steps of borg and gall & Detailed steps of research \\
\hline Research and Information gathering & $\begin{array}{l}\text { Research and Information } \\
\text { collection }\end{array}$ & $\begin{array}{l}\text { Observation } \\
\text { Observing the atmosphere of learning to write poetry } \\
\text { through pictures } \\
\text { Recording all potential and learning problems of } \\
\text { writing poetry } \\
\text { Analyzing the needs of teachers and students through } \\
\text { questionnaires and interviews } \\
\text { Literature review } \\
\text { Analyzing the material used so far relates to writing } \\
\text { poetry through the picture media } \\
\text { curriculum analysis }\end{array}$ \\
\hline Planning & Planning & $\begin{array}{l}\text { Planning: a) Syllabus; b) Learning activity of writing } \\
\text { poetry; c) LCD Media; } 4 \text {. The evaluation tool is a test }\end{array}$ \\
\hline Product development & Initial product development & $\begin{array}{l}\text { Product development of writing poetry teaching } \\
\text { materials prototype through pictures }\end{array}$ \\
\hline Field test and model revision & $\begin{array}{l}\text { Initial field test } \\
\text { Product Revision } \\
\text { Main field test } \\
\text { Product revision } \\
\text { Field test oprasional }\end{array}$ & $\begin{array}{l}\text { Expert assessment (validity test) } \\
\text { Peers Test } \\
\text { Legibility test (conformity test) } \\
\text { Model feasibility test (effectiveness test) }\end{array}$ \\
\hline Final product revision & Final product revision & $\begin{array}{l}\text { The final model of the teaching materials of the } \\
\text { pictured-assisted writing poetry }\end{array}$ \\
\hline Dissemination and implementation & Dissemination & \\
\hline
\end{tabular}

Table 2. Needs of syllabus recapitulation

\begin{tabular}{|c|c|c|c|c|c|c|c|}
\hline \multirow[t]{2}{*}{ No. } & \multirow[t]{2}{*}{ Description } & \multicolumn{5}{|c|}{ Percentage ofanswers (\%) } & \multirow[t]{2}{*}{ Total $(\%)$} \\
\hline & & SD & D & KD & TD & STD & \\
\hline 1 & Competency standards & 66,67 & 33,33 & 0 & 0 & 0 & 100 \\
\hline 2 & Basic competencies & 100 & 0 & 0 & 0 & 0 & 100 \\
\hline 3 & Indicator & 66,67 & 3.33 & 0 & 0 & 0 & 100 \\
\hline \multirow[t]{2}{*}{4} & Goals, evaluation/drills & 33,33 & 33,33 & 33,33 & 0 & 0 & 100 \\
\hline & Average (\%) & 66,67 & 24,99 & 8.33 & 0 & 0 & 100 \\
\hline
\end{tabular}

SD: Very Needed, D: Needed, KD: Less Needed, TD: Not Needed, STD: Very Unneeded

Table 3. Recapitulation of writing poetry teaching material needs

\begin{tabular}{llcccccc}
\hline \multirow{2}{*}{ No. } & Description & \multicolumn{3}{c}{ Percentage of answers (\%) } & \multicolumn{2}{c}{ Total (\%) } \\
\cline { 3 - 6 } & & SD & D & KD & TD & STD & 100 \\
\hline 1 & Teaching material & 66,67 & 33,33 & 0 & 0 & 0 & 0 \\
2 & Theme & 66,67 & 33.33 & 0 & 0 & 0 & 100 \\
3 & Design of teaching material & 33,33 & 66,67 & 0 & 0 & 0 & 100 \\
4 & Goals, evaluation/drills & 66,67 & 33,33 & 0 & 0 & 0 & 100 \\
5 & Advantages & 33.33 & 66,67 & 0 & 0 & 0 & 100 \\
\hline
\end{tabular}

researcher analyzes the learning objectives to be achieved. As a result, researchers developed the goal of writing poetry writing. Furthermore, in order to realize the contextual evaluation problem, the researcher performs the performance test of poetry writing according to the chosen theme. Thus, students are given the freedom to pour ideas or ideas in accordance with the chosen theme but still pay attention to aspects or requirements of writing poetry.
The next stage is the realization of pedagogic that is realized by the preparation of learning instructions, materials, exercises, evaluations presented in writing materials pantun results of development. The activity chosen to help students understand the writing of poetry is the practice of writing poetry.

After the contextual and pedagogic realization stage, the next step is the instructional product. The teaching materi- 
als produced in the form of a poem writing module with the title Ayo Belajar Menulis Puisi. Before teaching materials are tested in schools on a limited basis, teaching materials should be assessed in advance by experts or experts in the field. Material specialists to assess material truths, linguists who assess language and clarity of information, presentation experts assess clarity of goals, presentation sequence, and motivation, and graphic expert who assess the aspects of graph.

The teaching materials that are developed based on the analysis of students and teachers' needs can be seen in Figure 1 below.

\section{Feasibility of Teaching Material of Writing Poetry Using Pictures Model}

The model feasibility test was performed after the model was obtained from peer assessment and small group or limited trial. Based on suggestions and feedback from peers and test results in the field, the model revision was made. To get a model that really suits the needs of students and teachers, then the feasibility test model. To conduct a model feasibility test, we need help and advice from a team of experts appointed by the institution. After being revised based on suggestions, criticisms and input from expert teams, then piloted on larger class groups. Here are the results of the assessment of three experts on the design of learning done on: 1) syllabus, 2) model of teaching materials Poetry Writing Using Pictures.

After the trial was limited to small groups and revised the model based on the deficiencies at the time of small group trial, then the expert judgment. The activity aims to perfect the results of developing a model of learning to write a decent poem and in accordance with the needs of students and teachers. Validation is executed when the design is ready to be test- ed in the field. The result is an input for the second repair. The instruments used are questionnaires, syllabus, and teaching materials. The final stage of development is to evaluate and revise. Evaluation or validation is done by three experts, i.e linguists, designers, and learning material experts.

\section{Linguist}

The linguist as validator for writing poetry materials by the pictures media provides input through the detailed stages of the questions that have been prepared by the researcher. The validator provides a checklist to the prepared statement and provides suggestions. To obtain validation of teaching materials is given an evaluation that includes: 1) the language of the teaching materials more simplified; 2) the language for elementary students must be straightforward; 3) differentiated teaching materials for teachers with teaching materials for students.

\section{Design expert}

The design validator for writing poetry learning provides a checklist on the statement column prepared by the researcher. Questions for design validators include: 1) colors made more contrast; 2) plus more pictures that match the theme.

\section{Materials expert}

Criticism, suggestions, and responses of teachers into consideration of the researcher into a very meaningful input for improvement of teaching materials; 1) teaching materials materials in accordance with the curriculum, only the theme needs to be expanded again; 2) interesting and simple material.

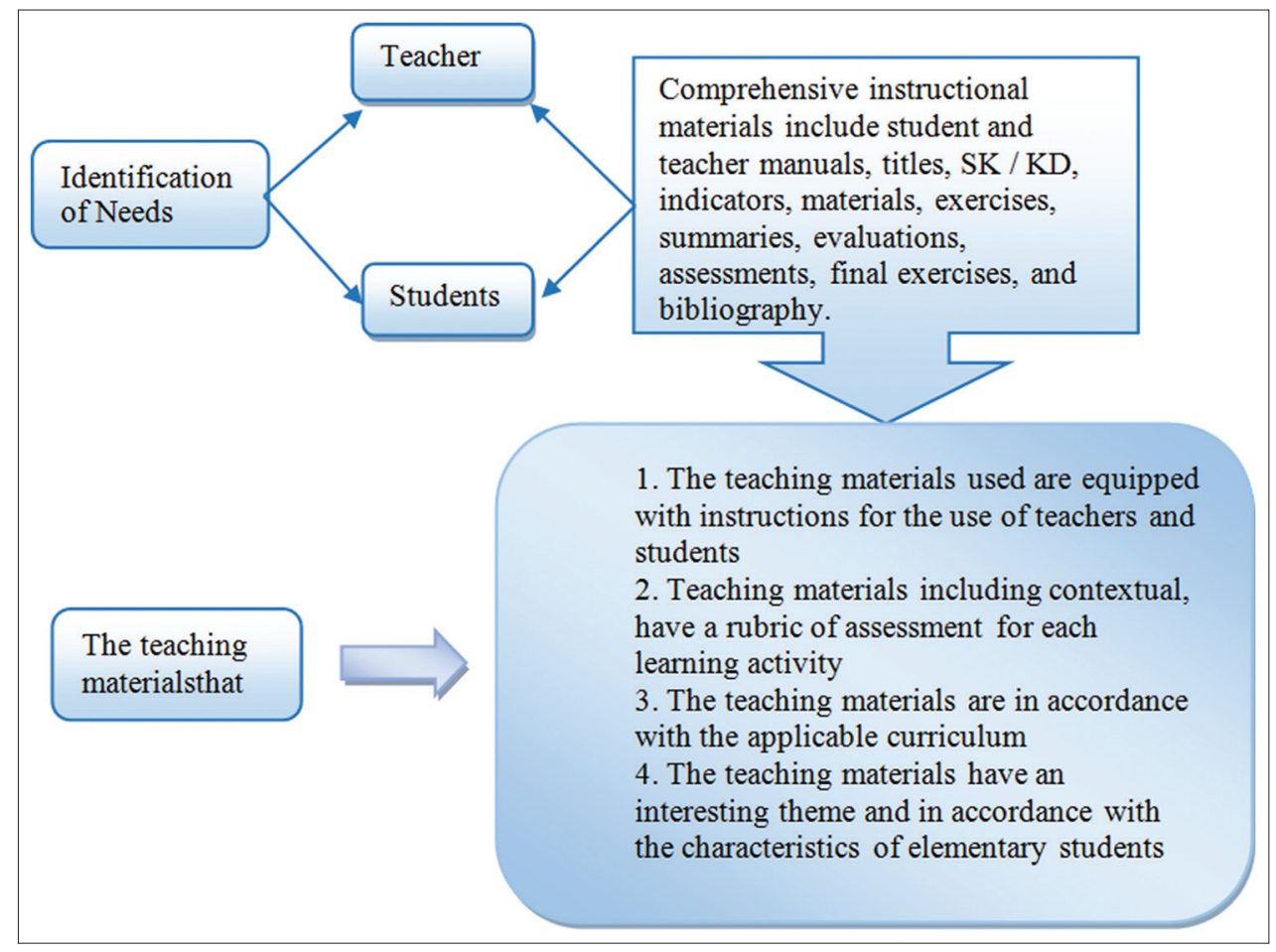

Figure 1. Design after Research 
The results of the assessment of the three vlidators can be seen in table 4 below:

Based on the assessment of the validators of language, graphs, and materials can be concluded that the teaching materials of the overall development of the results declared good or feasible to use. Teaching materials produced from the research can be used by students of grade V SD in Lubukliggau City in both high, medium and low category. This is seen from the validation results obtained average score of 27.33 with an average percentage of $79.4 \%$. The three validators provide recommendation that the teaching material of Poetry Writing Using Pictures has been feasible for poetry writing. The following table 4 shows the recapitulation of the results of the three validators.

\section{The Application Effectiveness of the Teaching Materials of Poetry Writing Using Pictures}

In order to know the effectiveness of instructional model of writing poetry assisted by the media of designed image, the research done through effectiveness test was done on 3 elementary schools, respectively 1 elementary school with high category, 1 elementary school with medium category, and 1 elementary school with low category. The data is confirmed to be normal by performing a normality test. The researcher in this case will compare between the final score with the $\mathrm{KKM}$ of each school as the respondent in this research:

In detail the results of large group trials can be explained as follows:

\section{High School Category Trial}

The learning process that was held at the first meeting was quite different when it was tested in small groups. The difference lies in the treatment of learning activities. Learning activities begin with apersepsi which aims to generate motivation and schemata of children, focusing attention on the learning process. Schemata can be interpreted to awaken a child to a concept that is networked and developed in the awareness of the child, and all of them need to be awakened through the theme and descriptive understanding of the theme presented. The next phase of the teacher explains the title/material to be conveyed and explains the purpose of studying the material. The next activity continued on the core activities by applying the pictures as media on poetry writing activities. The results of high category trials can be seen in the following table 5.

The SPSS results in table 6 show that the data is normally distributed, indicated by Asymp.Sig. (2-tailed) $0.03<$ 0.05 . As in table 7 shows the value for $t_{\text {count }}$ value 11,219 and $t_{\text {table }} 2.045$ for (d) 30 and alpha 0,05 , thereby can be concluded $\mathrm{t}_{\text {count }}>\mathrm{t}_{\text {table }}$, so $\mathrm{H} 0$ is rejected, and $\mathrm{H} 1$ accepted, mean value mean learning mastery students in grade V SD Xaverius after using teaching material of Poetry Writing Using Picture is equal to 75 or more than 75 .

\section{Large group trials in medium category school}

SPSS results in table 8 and table 9 show that the data is normally distributed, indicated by Asymp.Sig. (2-tailed) 0,0001 $<0,05$. As in table 10 shows for $t_{\text {count }}$ value of 9,416 and $t_{\text {ta- }}$ ble 2,042 for (d) 30 and alpha 0,05, hence can be concluded $\mathrm{t}_{\text {count }}>\mathrm{t}_{\text {table }}$, so H0 is rejected, and H1 accepted, mean value mean learning mastery students in the elementary school class 44 after using teaching material of Poetry Writing Using Picture is equal to 70 or more than 70 .

\section{Large group trial on category low school}

The SPSS result start from table 11 and generate distribution in table 12 shows that the data is normally distributed, indicated by Asymp.Sig. (2-tailed) 0,0001. As in table 13 shows for the value of t-count 4,859 and t-table 2,110 for (d) 17 and alpha 0,05 , hence can be concluded t-count $>t$-table, so H0 is rejected, and $\mathrm{H} 1$ accepted, mean value mean learning mastery after using teaching material of Poetry Writing Using Picture is equal to 65 or more than 65 .

\section{CONCLUSION}

The following concludes the results of the study that links to the main aim and goals of the research problem:

First, the result of needs analysis, from 3 respondents of grade V elementary school, they hoped that the teaching material of Poetry Writing Using Picture used as the learning material of Indonesian language with time every 2 hour week or given a balanced time with other subject.

Second, Second, the teaching materials to write the resulting image-generated poems are taken through the following stages: 1) analysis of the needs of students and teachers on teaching materials; 2) curriculum, SK, and KD analysis; 3) pedagogical analysis embodied in the form of learning, exercise materials, and evaluation; 4) trials of small groups and large groups; 5) every test phase is firstly performed by expert judgments; and 4) After the experts provide an assessment, then created the materials that suit the needs of students and teachers.

Third, the results of the evaluation of the three experts indicate that the developed teaching materials for writing poetry is eligible and relevant used in terms of aspects 1) teach-

Table 4. Recapitulation assessment of three validators

\begin{tabular}{llccc}
\hline No. & Validator & Assessment result & Percentage & Category \\
\hline 1 & Linguist & 13 & 65 & Good \\
2 & Graph expert & 38 & 84,44 & Good \\
3 & Materials expert & 31 & 88,76 & Very good \\
& Average & 27,33 & 79,4 & Good \\
\hline
\end{tabular}


Table 5. Descriptive statistics

\begin{tabular}{|c|c|c|c|c|c|}
\hline & $\mathbf{N}$ & Minimum & Maximum & Mean & Standard deviation \\
\hline Pretest & 30 & 50,00 & 83,00 & 72,3333 & 7,99281 \\
\hline Postest & 30 & 63,00 & 93,00 & 80,1667 & 6,65444 \\
\hline Valid N (listwise) & 30 & & & & \\
\hline
\end{tabular}

Table 6. Normality test writing poetry test result One-sample kolmogrov-smirnov test

\begin{tabular}{lcc}
\hline One-sample kolmogorov-smirnov test & Pretest & Postest \\
\hline N & 30 & 30 \\
Normal parameters ${ }^{\mathrm{a}, \mathrm{b}}$ & 72,3333 & 80,1667 \\
$\quad$ Mean & 7,99281 & 6,65444 \\
Standard deviation & & 0,223 \\
Most extreme differences & 0,331 & 0,134 \\
Absolute & 0,139 & $-0,223$ \\
Positive & $-0,331$ & 1,223 \\
Negative & 1,811 & 0,100 \\
Kolmogorov-Smirnov Z & 0,003 & \\
Asymp. Sig. (2-tailed) & & \\
\hline
\end{tabular}

a. Test distribution is normal.

b. Calculated from data.

Table 7. T-test result of writing poetry test

\begin{tabular}{|c|c|c|c|c|c|c|c|c|}
\hline \multicolumn{9}{|c|}{ Paired samples test } \\
\hline & \multicolumn{5}{|c|}{ Paired differences } & \multirow[t]{3}{*}{$\mathbf{t}$} & \multirow[t]{3}{*}{ df } & \multirow[t]{3}{*}{ Sig. (2-tailed) } \\
\hline & \multirow[t]{2}{*}{ Mean } & \multirow[t]{2}{*}{$\begin{array}{l}\text { Standard } \\
\text { deviation }\end{array}$} & \multirow[t]{2}{*}{$\begin{array}{c}\text { Standard } \\
\text { error mean }\end{array}$} & \multicolumn{2}{|c|}{$\begin{array}{c}95 \% \text { Confidence interval } \\
\text { of the difference }\end{array}$} & & & \\
\hline & & & & Lower & Upper & & & \\
\hline \multicolumn{9}{|l|}{ Pair 1} \\
\hline Postest - Pretest & 7,83333 & 3,82445 & 0,69825 & 6,40526 & 9,26141 & 11,219 & 29 & 0,000 \\
\hline
\end{tabular}

Table 8. Descriptive statistics

\begin{tabular}{lcccccc}
\hline & N & Minimum & Maximum & Sum & Mean & Standard deviation \\
\hline Pretest & 31 & 40,00 & 78,00 & 2056,00 & 66,3226 & 10,46387 \\
Postest & 31 & 50,00 & 85,00 & 2317,00 & 74,7419 & 7,30738 \\
Valid N & 23 & & & & & \\
$($ listwise) & & & & & & \\
\hline
\end{tabular}

ing materials; 2) theme; 3) design of teaching materials; 4) objectives, evaluation/training; and 5) benefits. However, in particular there are some of these points received major attention in the improvement of teaching materials at the next stage. Comments and suggestions submitted by notes are best used in the revision of instructional materials. The test results of each meeting always show an increase in the value before applying the teaching materials with after applying the teaching materials. The increase in value occurs because of the students' interest to write poetry. The results of limited trials also indicate that in general teaching materials that have been tested, feasible, and good, and able to improve the ability to write poetry.

Fourth, the results of product effectiveness test of experimental model conducted by using experiment proves that t-test of teaching materials developed is very significant. Because of the three schools sampled in the study results obtained $t_{\text {count }}$ greater than $t_{\text {table }}$ or in critical areas, $\mathrm{H} 0$ rejected, meaning that the process of writing poetry of students grade V SD proved effective. Thus, this can be concluded that the research product development of teaching materials for writing poetry for grade V SD students in Lubuklinggau has its own characteristics with other teaching materials. Thus, the model of teaching ma- 
terials developed has been feasible and effective from the academic/expert side, practically teachers, and especially field-based.

Table 9. Normality test writing poetry test result

\begin{tabular}{lcc}
\hline \multicolumn{2}{l}{ One-sample kolmogrov-smirnov test } & \\
\hline \multicolumn{2}{l}{ Pretest } & Postest \\
\hline $\mathrm{N}$ & 31 & 31 \\
Normal parameters ${ }^{\mathrm{a}, \mathrm{b}}$ & 66,3226 & 74,7419 \\
$\quad$ Mean & 10,46387 & 7,30738 \\
$\quad$ Standard deviation & & \\
Most extreme differences & 0,283 & 0,192 \\
Absolute & 0,145 & 0,107 \\
Positive & $-0,283$ & $-0,192$ \\
Negative & 1,573 & 1,066 \\
Kolmogorov-Smirnov Z & 0,014 & 0,206 \\
Asymp. Sig. (2-tailed) &
\end{tabular}

a. Test distribution is Normal.

b. Calculated from data.

\section{IMPLICATION}

First, teaching material of Poetry Writing Using Picture that are packaged in the material specially writing poetry is one alternative teaching materials that can be used by third graders elementary school in teaching and learning activities. Second, for educational institutions, teaching materials of Poetry Writing Using Picture that are packaged in special materials to write poetry are one alternative teaching materials that can be used by students of grade V SD in Indonesian language subjects. In addition, teaching materials are generated based on needs assessment (need assessment) of students and teachers, so that their wishes have been fulfilled by the teaching materials produced. Third, for teachers and other researchers, teaching materials of Poetry Writing Using Picture can be used as a reference and source of information to conduct further research, especially research development with other learning models tailored to the objectives and learning materials. Fourth, for the user community, teaching materials of Poetry Writing Using Picture can provide motivation and development of new ideas related to the Indonesian learning model, the readers are expected to produce works by devel-

Table 10. T-test result of writing poetry test

\begin{tabular}{|c|c|c|c|c|c|c|c|c|}
\hline \multicolumn{9}{|c|}{ Paired samples test } \\
\hline & \multicolumn{5}{|c|}{ Paired differences } & \multirow[t]{3}{*}{$\mathbf{t}$} & \multirow[t]{3}{*}{ Df } & \multirow[t]{3}{*}{ Sig. (2-tailed) } \\
\hline & \multirow[t]{2}{*}{ Mean } & \multirow[t]{2}{*}{$\begin{array}{l}\text { Standard } \\
\text { deviation }\end{array}$} & \multirow[t]{2}{*}{$\begin{array}{c}\text { Standard } \\
\text { error mean }\end{array}$} & \multicolumn{2}{|c|}{$\begin{array}{l}\text { 95\% Confidence } \\
\text { interval of the } \\
\text { difference }\end{array}$} & & & \\
\hline & & & & Lower & Upper & & & \\
\hline \multicolumn{9}{|l|}{ Pair 1} \\
\hline Postest - Pretest & 8,41935 & 4,97845 & 0,89416 & 6,59325 & 10,24546 & 9,416 & 30 & 0,000 \\
\hline
\end{tabular}

Table 11. Descriptive statistics

\begin{tabular}{llccccc}
\hline & N & Minimum & Maximum & Sum & Mean & Standard deviation \\
\hline Pretest & 18 & 30,00 & 78,00 & 1103,00 & 61,2778 & 15,37686 \\
Postest & 18 & 45,00 & 80,00 & 1266,00 & 70,3333 & 9,31791 \\
Valid N (listwise) & 18 & & & & & \\
\hline
\end{tabular}

Table 12. Normality test writing poetry test result

\begin{tabular}{|c|c|c|}
\hline \multicolumn{3}{|c|}{ One-sample kolmogrov-smirnov test } \\
\hline & Pretest & Postest \\
\hline \multicolumn{3}{|l|}{$\mathrm{N}$} \\
\hline Normal parameters $\mathrm{s}^{\mathrm{a}, \mathrm{b}}$ & 18 & 18 \\
\hline Mean & 61,2778 & 70,3333 \\
\hline Standard deviation & 15,37686 & 9,31791 \\
\hline \multicolumn{3}{|l|}{ Most extreme differences } \\
\hline Absolute & 0,270 & 0,247 \\
\hline Positive & 0,138 & 0,150 \\
\hline Negative & $-0,270$ & $-0,247$ \\
\hline Kolmogorov-Smirnov Z & 1,147 & 1,049 \\
\hline Asymp. Sig. (2-tailed) & 0,144 & 0,221 \\
\hline
\end{tabular}

\footnotetext{
a. Test distribution is Normal.
}

b. Calculated from data. 
Table 13. T-test result of writing poetry test

\begin{tabular}{|c|c|c|c|c|c|c|c|c|}
\hline \multicolumn{9}{|c|}{ Paired samples test } \\
\hline & \multicolumn{3}{|c|}{ Paired differences } & & & \multirow[t]{3}{*}{$\mathbf{t}$} & \multirow[t]{3}{*}{ Df } & \multirow[t]{3}{*}{ Sig. (2-tailed) } \\
\hline & \multirow[t]{2}{*}{ Mean } & \multirow[t]{2}{*}{$\begin{array}{l}\text { Standard } \\
\text { deviation }\end{array}$} & \multirow[t]{2}{*}{$\begin{array}{c}\text { Standard } \\
\text { error mean }\end{array}$} & \multicolumn{2}{|c|}{$\begin{array}{l}\text { 95\% Confidence } \\
\text { interval of the } \\
\text { difference }\end{array}$} & & & \\
\hline & & & & Lower & Upper & & & \\
\hline \multicolumn{9}{|l|}{ Pair 1} \\
\hline Postest - Pretest & 9,05556 & 7,90735 & 1,86378 & 5,12332 & 12,98779 & 4,859 & 17 & 0,000 \\
\hline
\end{tabular}

oping the creativity of writing in literary materials. Fifth, for students and students, with the presence of teaching materials of Poetry Writing Using Picture to be an example to always do writing activities in the form of research and other works. Teaching materials can be illustrations to develop learning materials to suit the users' wishes.

\section{REFERENCES}

Alkhaldi, A.A. (2010). Developing a Principled Framework for Materials Evaluation: Some Considerations. Advances in Language and Literary, 1(2), pp. 281-284. Doi:10.7575/aiac.alls.v.1n.2p.281

Borg, W. R. \& Gall. (1989). Educational Research: An Introduction. Fifth Edition. New York: Longman.

Dalman. (2014). Keterampilan Menulis. Jakarta. PT Raja Grafindo Persada.

Noermanzah, N. N. (2017). Plot in a Collection of Short Stories "Sakinah Bersamamu" Works of Asma Nadia with Feminimism Analysis. Humanus, 16(1), p. 27. https:// doi.org/10.24036/jh.v16i1.7015
Pradopo, R.D. (2005). Beberapa Teori Sastra, Metode Kritik, dan Penerapannya. Yogyakarta: Pustaka Pelajar.

Prastowo. (2011). Panduan Kreatif Membuat Bahan Ajar Inovatif. Jakarta: Diva Press.

Setiawan, D. (2007). Pengembangan Bahan Ajar. Jakarta: Universitas Terbuka.

Sugiyono. (2012). Metode Penelitian Pendidikan: Pendekatan Kuantitatif, Kualitatif, dan R \& D. Bandung: Alfabeta.

Sukmadinata, N.S. (2008). Metode Penelitian Pendidikan. Jakarta: Remaja Rosdakarya.

Tarigan, H.G. (2008). Menulis sebagai Suatu Keterampilan Berbahasa. Bandung: Angkasa.

Wahyuni, R. (2014). Kitab Lengkap Puisi, Prosa, dan Pantun Lama. Jakarta Selatan.Saufa.

Zafarmand, A., Ghanizadeh, A., \& Akbar, O. (2014). A Structural Equation Modeling of EFL Learners' Goal Orientation, Metacognitive Awareness, and Self-Efficacy. Advances in Language and Literary Studies, 8(6) pp. 112-113. Doi:10.7575/aiac. alls.v.5n.6p.112 